\title{
Effectiveness of the Ageratum (Ageratum conyzoides) Leaf Extract as Botanical Fungicide Against Twisted Disease of Shallot
}

\author{
Efektivitas Ekstrak Daun Ageratum (Ageratum conyzoides) Sebagai Fungisida Botani \\ terhadap Penyakit Moler Bawang Merah
}

\author{
Rianosa Rianosa ${ }^{1}$, Hartal Hartal $^{2}$, Nanik Setyowati $^{3 *}$
}

\author{
${ }^{1}$ Program Study of Agroecotechnology, Bengkulu University, Bengkulu 38371 \\ ${ }^{2}$ Department of Plant Protection, Faculty of Agriculture, Bengkulu University, Bengkulu 38371 \\ ${ }^{3}$ Department of Agriculture Cultivation, Faculty of Agriculture, Bengkulu University, Bengkulu 38371 \\ ${ }^{*}$ Corresponding author: nsetyowati@unib.ac.id
}

(Received: 18 September 2019, Accepted: 24 March 2020)

Citation: Rianosa R, Hartal H, Setyowati N. 2020. Effectiveness of the Ageratum (Ageratum conyzoides) leaf extract as botanical fungicide against moler diseases of shallot. Jurnal Lahan Suboptimal: Journal of Suboptimal Lands 9(1): 1-10.

\begin{abstract}
ABSTRAK
Penyakit moler merupakan penyakit utama yang dapat menurunkan kualitas dan kuantitas produksi bawang merah. Aplikasi fungisida sintetik terbukti efektif untuk mengendalikan penyakit ini, namun penggunaan dalam jangka panjang dapat meracuni organisme non-target dan merusak lingkungan. Daun bandotan (Ageratum conyzoides) yang dianggap gulma ternyata berpotensi sebagai anti jamur, anti bakteri bahkan anti kanker. Oleh karena itu, penelitian ini bertujuan untuk menentukan konsentrasi ekstrak daun bandotan yang paling efektif dalam mengendalikan penyakit moler pada bawang merah secara in vivo serta membandingkan efektivitasnya dengan fungisida sintetik. Penelitian menggunakan Rancangan Acak Lengkap dengan faktor tunggal yang terdiri dari 5 perlakuan fungisida nabati ekstrak daun bandotan (konsentrasi $1 \%$ sampai 5\%), 2 perlakuan fungisida sintetik (mankozeb dan metil tiofanat) sebagai pembanding serta 1 perlakuan kontrol (tanpa fungisida dengan media tanam steril). Ekstrak daun bandotan didapatkan dengan metode maserasi menggunakan etanol $96 \%$. Aplikasi fungisida hanya dilakukan sekali pada umbi bawang merah sebelum tanam. Hasil penelitian menunjukkan, fungisida nabati dari ekstrak daun bandotan efektif dalam mengendalikan penyakit moler pada bawang merah. Konsentrasi 4\% ekstrak daun bandotan memiliki efektivitas yang sebanding dengan fungisida mankozeb dalam mengendalikan penyakit moler serta mampu meningkatkan hasil tanaman bawang merah. Dengan demikian ekstrak daun bandotan dapat dijadikan pengganti fungisida sintetik dalam mengendalikan penyakit moler pada bawang merah.
\end{abstract}

Kata kunci: bandotan, fungisida nabati, fungisida sintetik, gulma, penyakit moler

\begin{abstract}
Twisted is a major disease of onion caused by Fusarium oxysporum $\mathrm{f}$. sp. cepae. Application of synthetic fungicides in the long-term has a negative effect to the environment. Weed leaves of Ageratum (Ageratum conyzoides) have potential to be an anti-fungal, anti-bacterial as well as anti-cancer. This study aimed to determine the best concentration of Ageratum leaf extract to control twisted disease and to compare the
\end{abstract}


effectiveness of botanical fungicide and synthetic fungicide. The experiment was consists of five Ageratum leaf extract concentrations as a botanical fungicide (i.e. 1\%, 2\%, 3\%, 4\%, and 5\%), and synthetic fungicide namely mancozeb and metil tiofanat and control treatment (in sterile soil with no fungicide treatment). The experiment used Completely Randomized Design (CRD) with a single factor. Ageratum leaf extract was obtained through the maceration method using ethanol $96 \%$. The application of fungicide was carried out on shallot bulbs before planting. The results showed botanical fungicides from Ageratum leaf extract were effective against twisted disease of shallots, concentration 4\% of Ageratum leaf extract resulted in a longer incubation period and lower disease intensity compared to other concentrations, and the effectiveness of Ageratum leaf extract at a concentration of $4 \%$ was comparable to that of mancozeb to control twisted disease. Application of both synthetic and botanical fungicide resulted in a higher yield of shallot. Therefore, Ageratum leaf extract has potential as a substitution of synthetic fungicides to control twisted disease of shallots.

Keywords: Ageratum, biopesticide, disease, Fusarium oxysporum, weed

\section{INTRODUCTION}

Shallot (Allium ascalonicum L.) is one of the leading vegetable commodities making an important contribution to the economic development of the region in Indonesia. This commodity is used for daily consumption and even become an industrial raw material (Badan Litbang Pertanian, 2005). The data of the Badan Pusat Statistik (2017) showed that the shallot productivity in Indonesia decreased by $3.93 \%$. The 2015 shallot production of 10.07 tons/ha declined to 9.64 tons/ha in 2016. On the other hand, the productivity of shallots in Bengkulu Province increased by $14.3 \%$; in 2015 the production increased from 5.12 tons/ha to 5.84 tons/ha in 2016. However, its productivity only fulfilled half of the national productivity. Consequently, an evaluation of the development of shallots is needed because this commodity was a national priority in 2018 and Indonesia is projected as the main exporter of shallots in ASEAN in 2045 (Direktur Jenderal Hortikultura, 2017). One of the main causes of the decrease of shallot productivity in Indonesia is the high attack of plantdisturbing organisms (PDO). Twisted disease is one of the main diseases in shallot cultivation caused by Fusarium oxysporum f.sp. cepae. Dean et al. (2012) states that $F$. oxysporum is the number 5 cause of damage in the world in agricultural cultivation which causes significant losses for farmers. F.oxysporum is a soil borne pathogen that can last a long time in the soil as saprophytes capable of infecting young plants from the field to the storage in warehouses by direct penetration or through wounds to roots and tubers (Michielse and Rep, 2009; Hasanuddin and Rosmayati, 2013). The damage of shallots due to this pathogen can reduce the economic value of shallot both in quality and quantity.

Shallot twisted disease is very difficult to control and prevention is needed from the beginning of planting. Application of synthetic fungicides on tubers before planting (seed treatment) has proven to be effective in controlling pathogens carried on seedlings and protecting them from soilborne pathogens (Agrios, 1996) but longterm use can cause environmental damage and contaminate non-target organisms with poison. In addition, some pathogens in agricultural land are resistant to synthetic fungicides; therefore, their development is difficult to control. There have to be other alternatives needed to control them. Vegetable fungicides are one of the promising solutions because their main ingredients are easily obtainable in nature. Allelopathy derived from the plant secondary metabolites is known to play an important role as plant protection such as anti-bacterial, anti-viral, anti-fungal, and plant-based insecticides (Hajlaoui et al., 
2009). The active substances contained in the plant allelopathy can be synthesized or used in extract form. Plant extracts are easily degraded quickly in the soil thereby reducing the impact on the environment and effective support for sustainable agriculture (Cho et al., 2006). Ageratum (Ageratum conyzoides) which belongs to the family Asteraceae is a weed that has the potential to produce allelopathy.

The allelopathy contained in Ageratum consists of alkaloids, flavonoids, chomenes, benzofuran, and terpenoids (Okunade, 2002). According to Xuan et al. (2004), extracts from Ageratum can control several pathogens in rice plants, it even has the potential to be anti-cancer (Adetutu et al., 2012). Ageratum extract also shows effectiveness comparable to the $50 \%$ iprodion fungicide in suppressing the severity of anthracnose in bananas (Arie et al., 2015). Therefore, this study aimed to find out the concentration of the most effective Ageratum leaf extract to control twisted disease in shallots and then compare the effectiveness of vegetable fungicides with synthetic fungicides in controlling twisted disease in shallot.

\section{MATERIALS AND METHODS}

The study was conducted at the Plant Protection Laboratory, Faculty of Agriculture, Bengkulu University and the green house in Medan Baru, Muara Bangkahulu District, Bengkulu City. The study used a Completely Randomized Design (CRD) with 8 treatments and 4 replications. In total there were 32 experimental units. The treatments consisted of 5 vegetable fungicide treatments $(1 \%, 2 \%, 3 \%, 4 \%$ and $5 \%$ of Ageratum leaf extract), 2 synthetic fungicide treatments (mankozeb and methyl thiophanate) and control (without fungicide with sterile growing media). Ageratum leaves used in the study derived from the Experimental Farm of the Faculty of Agriculture, Bengkulu University.
The Ageratum leaf extraction process was carried out by maceration method using ethanol $96 \%$ for 48 hours. The maceration results in the form of filtrate were obtained by filtering using filter paper, then the collected filtrate was evaporated with a rotary vacuum evaporator at $40^{\circ} \mathrm{C}$ so that Ageratum leaf extract was obtained. Concentration of vegetable fungicide was obtained by dissolving $0.5 \mathrm{~g} ; 1 \mathrm{~g} ; 1.5 \mathrm{~g} ; 2 \mathrm{~g}$ and $2.5 \mathrm{~g}$ of Ageratum leaf extract into sterile distilled water to a volume of $50 \mathrm{ml}$ each to obtain a concentration of Ageratum extracts of $1 \%, 2 \%, 3 \%, 4 \%$ and $5 \%$. Bauji shallot varieties and planting media in this study derived from the UPTD Balai Benih Hortikultura (BBH) in Kepahiang District of Bengkulu Province, which were suspected to have been contaminated with $F$. oxysporum.

The planting media consisted of a mixture of soil and cow manure with a weight ratio of $2: 1$. Specifically the control treatment used planting media sterilized using autoclaves at $121^{\circ} \mathrm{C}$ with a pressure of $2 \mathrm{~atm}$ for 30 minutes. The day before planting and the application of fungicides, the upper third of the bulbs of the shallot was cut so that the growth was uniform. The application of vegetable fungicide was conducted by soaking the shallot tubers for 1 hour in $50 \mathrm{ml}$ of Ageratum leaf extract solution based on the treatment added with $2 \%$ Tween 80 adhesive (v/v).

The synthetic fungicide application was carried out by soaking tubers in a pesticide solution at a dose of $2 \mathrm{~g} / \mathrm{L}$ for the past 5 minutes. After being soaked, the tubers were aerated for 2 hours in a clean place at room temperature. The application of this fungicide was only done once before the seedlings were planted. After the application of fungicide, the shallots were planted into a $30 \mathrm{x} 30 \mathrm{~cm}$ polybag containing $5 \mathrm{~kg}$ of growing media in each polybag. The shallots were harvested on the 66 days after planting. 
Table 1. Scale of the disease severity

\begin{tabular}{ll}
\hline Score & \multicolumn{1}{c}{ Severity } \\
\hline 0 & Apparently infection -free; \\
1 & Trace - 25\% leaf area infected; \\
2 & $26 \%-50 \%$ leaf area infected; \\
3 & $51 \%-75 \%$ leaf area infected; \\
4 & $>75 \%$ leaf area infected; \\
5 & Plant dead \\
\hline Source: Bock et al., 2010
\end{tabular}

Table 2. Analysis of variance (ANOVA) of all variable tested

\begin{tabular}{lrr}
\hline Variable & F-value & F -table \\
\hline Incubation period & $0,65 \mathrm{~ns}$ & 2,42 \\
Disease incidence & $1,1 \mathrm{~ns}$ & 2,42 \\
Percent severity index & $3,5 * *$ & 2,42 \\
Plant height & $10,65 * *$ & 2,42 \\
Number of leaves & $1,32 \mathrm{~ns}$ & 2,42 \\
Wet weight crown & $1,86 \mathrm{~ns}$ & 2,42 \\
Dry weight crown & $1,57 \mathrm{~ns}$ & 2,42 \\
Wet weight bulb & $2,96 *$ & 2,42 \\
Dry weight bulb & $3,38^{*}$ & 2,42 \\
Number of bulb & $1,38 \mathrm{~ns}$ & 2,42 \\
Bulb size & $2,47 *$ & 2,42 \\
\hline
\end{tabular}

Remarks: ns $=$ not significant, $*=$ significantly different, $* *=$ highly significantly different

The observations were made on the variables of disease, growth, and yield of shallots. The disease variables consisted of incubation period (days), DI (Disease Incidence) (\%) and PSI (Percent Severity Index) (\%). Growth and yield variables consisted of plant height $(\mathrm{cm})$, number of leaves, crown fresh weight $(\mathrm{g})$, bulb fresh weight (g), number of bulb, bulb size (g/bulb), crown dry weight ( $\mathrm{g}$ ) and bulb dry weight $(\mathrm{g})$.

$\mathrm{DI}=\frac{\text { Number of infected plants }}{\text { Total number of plants }} \times 100 \%$

PSI $=\frac{\sum(n x r)}{R x T} \mathrm{X} 100 \%$

Remarks:

DI $=$ Disease Incidence, PSI $=$ Percent Severity Index, $\mathrm{n}=$ number of infected leaf at the score, $\mathrm{r}=$ score (Table 1 ), $\mathrm{R}=$ maxium score on scale dan $\mathrm{T}$ $=$ total number of leaf

The collected data were statistically analyzed using analysis of variance (F-test) at a level $(\alpha)$ of $5 \%$ using the statistical software CoStat. The significantly different and highly significantly different results were further tested with Duncan's Multiple Range Test (DMRT) of 5\%.

\section{RESULTS AND DISCUSSION}

\section{Research Overview}

The study was conducted at Medan Baru Green House, Bangkahulu Subdistrict, Bengkulu City at an altitude of $7 \mathrm{~m}$ above sea level with soil temperatures between $25^{\circ} \mathrm{C}-35^{\circ} \mathrm{C}$, soil $\mathrm{pH}$ ranged from 6.0 to 7.0 and soil moisture ranged from $70 \%$ to $90 \%$. Rahayu and Berlian (2000) and Susanti et al. (2016) stated that the environmental conditions were in accordance with the conditions for growing shallots and the development of isolates of $F$. oxysporum f.sp. cepae of the Bauji variety shallot plant so that this research could run well until the harvest. All shallot plants got twisted disease, including the control plants. Previously, it was hoped that the control plants would not be attacked by the twisted disease because they were planted on sterile growing media. This attack still occurred allegedly due to pathogens carried on the shallot seedlings from the previous planting (seed born) (Artati, 1999; Bernadip et al., 2015). This proves that the land used for shallot cultivation in BBH in Kepahiang District was contaminated by the pathogen $F$. oxysporum that the seeds carried it with them. The results of the analysis of all variables are presented (Table 2).

\section{Fungicide Efficacy on Twisted Disease in Shallots}

The observation of disease variables on shallot plants was incubation period, percentage of attack and intensity of attack. The incubation period of twisted shallot began to be observed from the first day of planting until the plants showed symptoms that were characterized by pale green leaves and curves (twisted) (Patil et al., 2018). In the first week, all plants did not show the symptoms of twisted disease. Table 3 shows that the fastest incubation period 
occurred in the treatment of plant fungicides of $1 \%$ Ageratum leaf extract on the 16.25 days after planting. The longest incubation period occurred in the treatment of plant fungicides of $4 \%$ Ageratum leaf extract and control plants on the 19.75 days after planting. These results were in line with the study of Wiyatiningsih (2010) that the incubation period of the fastest twisted disease in Bauji varieties shallot without fungicide treatment ranged from the 12.721 days after planting. The length of the incubation period in the $4 \%$ Ageratum leaf extract fungicide treatment on shallot shows that this treatment is the best in inhibiting the development of twisted disease although the results of the analysis between treatments were not significantly different.

The percentage of disease attack was observed to find out the percentage of the number of plants affected by twisted disease of the total shallot plants without looking at the severity of the disease. Table 3 shows that the percentage of attacks on 2 WAP only occurred in the treatment of vegetable fungicides of $1 \%$ Ageratum leaf extract by $25 \%$ or about $3 \%$ of the entire plant observed. However, the percentage of twisted disease attacks increased very drastically on 3 WAP, which was equal to $81 \%$ and finally all plants showed early symptoms of twisted disease at 4 WAP.

The intensity of the attack was observed to find out the severity of twisted disease on shallots. Table 3 shows that the higher the concentration of vegetable fungicide of
Ageratum leaf extract is, the lower the intensity of twisted disease shallots will be. At a concentration of 2\%-5\% Ageratum leaf extract was significantly different when compared to the control treatment and $1 \%$ Ageratum leaf extract.In addition, the plantbased fungicides were better when compared to mankozeb and methyl thiophyanate synthetic fungicides in inhibiting the attack of twisted disease, although not statistically significantly different.

\section{Fungicides Efficacy on Shallots Growth and Yield}

Plant height, number of leaves, and crown weight are the most important aspects to measure the growth of shallot because they are able to indicate the results of photosynthates in plants which will later be translocated to the important parts of the plant especially for the formation of shallot bulb (Elisabeth et al., 2013).

Table 4 shows that all shallot plants treated with fungicides (both plant and synthetic fungicides) had plant heights ranging from $40.25 \mathrm{~cm}$ to $43.25 \mathrm{~cm}$, significantly different compared to that of the control plants $(28.5 \mathrm{~cm})$. The number of leaves was in accordance with the description of shallots varieties, which were $35 \mathrm{~cm}-43 \mathrm{~cm}$ (Baswarsiati et al., 2013). The results of this study indicate that the disease- controlled plants resulted in the higher plants height.

Table 3. Effects of fungicide on twisted diseases incidence of shallot

\begin{tabular}{|c|c|c|c|c|c|}
\hline \multirow{2}{*}{ Treatment } & \multirow{2}{*}{$\begin{array}{l}\text { Incubation Period } \\
\text { (DAP) }\end{array}$} & \multicolumn{3}{|c|}{ Disease Incidence (\%) } & \multirow{2}{*}{ PSI (\%) } \\
\hline & & $2 \mathrm{WAP}$ & 3 WAP & 4 WAP & \\
\hline 1\% Ageratum extract & 16,25 & 25 & 100 & 100 & $33,00_{a}$ \\
\hline $2 \%$ Ageratum extract & 18,50 & 0 & 100 & 100 & $19,75_{b}$ \\
\hline $3 \%$ Ageratum extract & 18,75 & 0 & 50 & 100 & $18,00_{b}$ \\
\hline $4 \%$ Ageratum extract & 19,75 & 0 & 50 & 100 & $17,75_{b}$ \\
\hline $5 \%$ Ageratum extract & 19,00 & 0 & 100 & 100 & $16,50_{\mathrm{b}}$ \\
\hline Mankozeb & 18,25 & 0 & 100 & 100 & $24,00_{\mathrm{ab}}$ \\
\hline Metil tiofanat & 19,00 & 0 & 75 & 100 & $22,25_{\mathrm{ab}}$ \\
\hline Control & 19,75 & 0 & 75 & 100 & $32,00_{\mathrm{a}}$ \\
\hline Total & & $3 \%$ & $81 \%$ & $100 \%$ & \\
\hline
\end{tabular}

Remarks: Numbers followed by the same letter in the same columns were not significantly different $(\alpha=5$ $\%)$. DAP $=$ day after planting, WAP $=$ week after planting, PSI $=$ Percent Severity Index 
The control treatment resulted in the lower plants heigh. This was due to the tip of the shallot leaf withered and dried. This symptom is an advanced symptom of twisted disease thus significantly reducing plant height (Patil et al., 2018). This is consistent with the results of the research conducted by Naguleswaran et al. (2014) that twisted caused by Fusarium can make the end of the plant experience necrosis. Lestiyani et al. (2016) also report that the diseases caused by Fusarium spp. can cause three symptoms of shallot plants in the form of wilting, twisted, and root decay.

Although there were no significant differences among the treatments, the leaves number of shallots showed good results, ranging from 43-74 strands/clump (Table 4). There were also no significantly different on the crown fresh weight and crown dry weight of shallot. This results showed that the growth of shallots was still going well even though being attacked by twisted disease. When the plants grow well, the photosynthesis activity in the leaves will run normally so that it can produce photosynthates better which will be reflected from the plant yield variables.

The main purpose of agricultural cultivation is to get good and economically valuable crops. The tuber yield is the most economical part and is as an indicator of the success of shallot cultivation. The fresh weight of shallots indicates that the plants still contain water in its tissues while the dry weight indicates the photosynthetic results produced by the plant during its growth. The accumulation of dry matter reflects the ability of plants to bind energy from the sunlight through the process of photosynthesis, as well as their interactions with other environmental factors.

Table 4. Effects fungicide on the growth and yield of shallot

\begin{tabular}{lcccc}
\hline Treatment & $\begin{array}{c}\text { Plant Height } \\
(\mathrm{cm})\end{array}$ & $\begin{array}{c}\text { Number of } \\
\text { Leaves }\end{array}$ & $\begin{array}{c}\text { Crown Fresh Weight } \\
(\mathrm{g} / \text { Clump })\end{array}$ & $\begin{array}{c}\text { Crown Dry Weight } \\
(\mathrm{g} / \text { Clump })\end{array}$ \\
\hline 1\% Ageratum extract & $40,25_{\mathrm{a}}$ & 56,5 & 32,78 & 3,93 \\
2\% Ageratum extract & $43,25_{\mathrm{a}}$ & 55,5 & 38,17 & 4,58 \\
3\% Ageratum extract & $41,25_{\mathrm{a}}$ & 65,5 & 33,45 & 4,18 \\
4\% Ageratum extract & $42,00_{\mathrm{a}}$ & 52,5 & 47,67 & 6,20 \\
5\% Ageratum extract & $42,75_{\mathrm{a}}$ & 49,0 & 47,84 & 5,58 \\
Mankozeb & $40,25_{\mathrm{a}}$ & 74,0 & 52,25 & 6,79 \\
Metil tiofanat & $41,50_{\mathrm{a}}$ & 43,0 & 33,96 & 3,91 \\
Control & $28,50_{\mathrm{b}}$ & 53,0 & 19,69 & 2,36 \\
\hline
\end{tabular}

Remarks: Numbers followed by the same letter in the same columns were not significantly different $(\alpha=5$ $\%)$

Table 5. Effects fungiside on the yield of shallot

\begin{tabular}{lcccc}
\hline Treatment & $\begin{array}{c}\text { Bulb FW Weight } \\
\text { (g/Clump) }\end{array}$ & $\begin{array}{c}\text { Bulb DW } \\
\text { (g/Clump) }\end{array}$ & Number of Bulb & $\begin{array}{c}\text { Bulb Size } \\
(\mathrm{g} / \text { Bulb })\end{array}$ \\
\hline 1\% Ageratum extract & $51,67_{\mathrm{ab}}$ & $7,57_{\mathrm{bc}}$ & 6,00 & $8,36_{\mathrm{a}}$ \\
$2 \%$ Ageratum extract & $43,85_{\mathrm{b}}$ & $7,92_{\mathrm{bc}}$ & 5,50 & $8,33_{\mathrm{a}}$ \\
$3 \%$ Ageratum extract & $35,29_{\mathrm{bc}}$ & $5,96_{\mathrm{bc}}$ & 8,25 & $6,59_{\mathrm{ab}}$ \\
$4 \%$ Ageratum extract & $53,66_{\mathrm{ab}}$ & $12,03_{\mathrm{ab}}$ & 6,75 & $8,64_{\mathrm{a}}$ \\
$5 \%$ Ageratum extract & $52,91_{\mathrm{ab}}$ & $9,91_{\mathrm{ab}}$ & 5,00 & $10,85_{\mathrm{a}}$ \\
Mankozeb & $67,47_{\mathrm{a}}$ & $15,11_{\mathrm{a}}$ & 10,50 & $6,70_{\mathrm{ab}}$ \\
Metil tiofanat & $41,90_{\mathrm{b}}$ & $6,71_{\mathrm{bc}}$ & 6,00 & $7,45_{\mathrm{a}}$ \\
Control & $15,90_{\mathrm{c}}$ & $1,89_{\mathrm{c}}$ & 6,75 & $2,32_{\mathrm{b}}$ \\
\hline
\end{tabular}

Remarks: FW: Fresh Weight, DW: Dry Weight Numbers followed by the same letter in the same columns were not significantly different $(\alpha=5 \%)$ 
Table 5 shows that there are significant differences in bulb weights among the treatments. The best bulb weights in the plant-based fungicide treatment were produced by the treatment of $4 \%$ extract $(\mathrm{FW}=53.66 \mathrm{~g} /$ clump and $\mathrm{DW}=12.03$ g/clump) which were not significantly different when compared to the synthetic fungicide mankozeb treatment $(\mathrm{FW}=67.47$ $\mathrm{g} /$ clump and $\mathrm{DW}=15.11 \mathrm{~g} / \mathrm{clump})$ and methyl thiophyanate $(\mathrm{FW}=41.90 \mathrm{~g} / \mathrm{clump}$ and $\mathrm{DW}=6.71 \mathrm{~g} / \mathrm{clump})$. Therefore, the application of vegetable fungicide Ageratum leaf extract can replace synthetic fungicides while increasing the yield of shallots. Looking at the number of bulb, the mankozeb fungicide treatment produced the highest number of bulb (10.50) while the number of bulb in the $4 \%$ treatment of Ageratum extract was the same as the control treatment (6.75). These results indicated that the number of shallots produced per clump from each treatment was not the same. In the control treatment, although the number of bulb produced was quite large, the weight was low, indicating that the size of the bulb was small. In addition, the shallot bulb in the control plants that had twisted disease was paler when compared to those of the fungicide treatment. Conversely, in the treatment of 4\% Ageratum leaf extract, the number of bulb produced was the same compared to the control plants but the weight was heavier, indicate a larger tuber size. Both of these phenomena were related to the plant health and the distribution of photosynthates resulting from the photosynthesis.

\section{Discussion}

In general, Ageratum extracts effectively control the twisted disease. The 4\% treatment of Ageratum leaf extract is able to produce a longer incubation period, lower attack intensity and better yields than other vegetable fungicide treatments. In addition, the treatment of plant-based fungicides has efficacy that was comparable to the treatment of synthetic fungicides. Ageratum contains secondary metabolites such as terpenes, sterols, flavonoids, alkaloids, benzofuran, chromen, chromon, coumarin, essential oils, and tannins so that these plants are believed to have many benefits and one of them is as an anti-microbial (Kamboj and Saluja, 2008).

The ability of Ageratum leaf extract to control twisted disease is the one which is strongly correlated with high flavonoid content in the leaves. Mohamed et al. (2017) state that the higher the level of flavonoids is, the more effective it is in reducing the growth of fusarium mycelium. This is because flavonoids are able to change the structure of the fusarium so that they are unable to attack plants properly. Javed and Bashir (2012) also reported that $6 \%$ of Ageratum leaf extract was able to reduce $78 \%$ of mushroom mass so that it was effective in controlling Fusarium solani.

The results of the research conducted by Sugito et al. (2010) showed that the use of plant-based fungicides could reduce the pathogen population of $F$. oxysporum without any negative impact on the growth of tomato plants. Therefore, the use of vegetable materials can save the cost of crop production to increase the value of agricultural products (Amoabeng et al., 2014). Although inexpensive and easily applied, the plant-based fungicides need to be applied periodically or repeatedly to get maximum results because the plant-based fungicides are derived from the plant materials which are easily degraded and quickly evaporate (Asikin, 2016). In general, mankozeb synthetic fungicides are effective in controlling twisted disease compared to other treatments. In fact, according to Patil and Nargund (2017), mankozeb is one of the most effective synthetic fungicides in controlling the disease of twisted shallot. This is because $80 \%$ of mankozeb consists of $62 \%$ diciocarbamate, $16 \%$ manganese, and $2 \%$ zinc. In addition to being able to control pathogenic fungi, mankozeb is able to increase nutrient fulfillment for plants so 
that they can grow optimally despite having the disease. Furthermore, mankozeb is also able to survive for 3 months before being degraded so that it can protect the tubers longer from the disease (Doneche et al., 1983). However, the use of mankozeb can reduce the population of soil fungi, especially antagonistic agents which results in the loss of the balance of soil ecosystems making it easier for resistant pathogens to attack plants (Sari et al., 2014; Lestari et al., 2018).

On the other hand, although methyl thiophyanate is a systemic synthetic fungicide, its effect is no more effective than mankozeb fungicide in controlling twisted disease. This is because mankozeb is a contact fungicide that is able to inhibit the early development of spores on the surface of shallot bulb so that it protects the shallot faster than methyl thiophanyate which is a systemic fungicide that takes longer to protect plants. In line with the study conducted by Vengadaramana and Costa (2014), although effective, the application of the methyl thiophyanate fungicide which is carried out only once before planting in shallot tubers is insufficient to control the twisteddisease as a whole.

In the control plants, almost all observed variables produced the lowest values except the number of leaves and tubers. Although the number of leaves and tubers produced was equivalent to other treatments, it still produced the lowest crown weight and the smallest tuber size.This is because $F$. oxysporum secretes several extracellular cellulolytic and pectinolytic enzymes after infection causing cell damage to shallot. The infected shallot tubers show disintegration of the epidermal layer and cortex tissue to make the plant metabolism disrupted (Malathi, 2013). In addition, Alberto (2014) reveals that twisted disease can cause a decrease in protein, sugar and phenol content so that it can decrease the resistance of the shallot. This is what causes the tuber size to be smaller and paler than those that receive fungicide treatment.

\section{CONCLUSION}

Botanical fungicide from Ageratum leaf extract was effective in controlling twisted disease in shallots. The $4 \%$ concentration of Ageratum extract is the best plant-based fungicide treatment resulting in a longer incubation period and low intensity of disease attack as well as resulting in canopy fresh weight, tuber fresh weight, and tuber dry weight higher than other concentrations. Ageratum leaf extract at a concentration of $4 \%$ has ability comparable to the mankozeb fungicide in controlling twisted disease and is able to increase the yield of shallots. Thus the Ageratum leaf extract can be used as a substitute for synthetic fungicides in controlling twisted disease in shallots.

\section{ACKNOWLEDGEMENT}

Our gratitude goes to the UPTD Balai Benih Hortikultura (BBH) of Kepahiang District, Bengkulu Province, which has facilitated researchers in the provision of Bauji variety shallot bulbs and planting media.

\section{REFERENCES}

Adetutu A, Morgan WA, Corcoran O, Chimezie F. 2012. Antibacterial Activity and in vitro cytotoxicity of Extracts and Fractions of Parkia biglobosa (Jacq.) Benth. stem bark and Ageratum conyzoides Linn. leaves. Environmental Toxicology and Pharmalogy. 34(1): 478-483.

Agrios GN. 1996. Ilmu Penyakit Tumbuhan (Munsir Busnia, translator). 3rd ed. Gadjah Mada University Press, Yogyakarta.

Alberto RT. 2014. Pathological response and biochemical changes in Allium cepa L. (bulb onions) infected with anthracnose-twister disease. Plant Pathology \& Quarantine 4(1): 23-31.

Amoabeng BW, Gurr GM, Gitau CW, Stevenson PC. 2014. Cost: Benefit 
analysis of botanical insecticide use in cabbage: Implications for smallholder farmers in developing countries. Crop Protection. 57(1): 71-76.

Arie IZ, Prasetyo J, Efri. 2015. Pengaruh ekstrak alang-alang, babadotan dan teki terhadap penyakit antraknosa pada buah pisang kultivar Cavendish. Jurnal Agrotek Tropika. 3(2): 251-256.

Artati SH. 1999. Inventarisasi cendawan terbawa bibit bawang merah. Skripsi. Institut Pertanian Bogor,

Bogor. https://repository.ipb.ac.id (diakses 14 Mei2019).

Asikin S. 2016. Dua jenis gulma sebagai pestisida nabati terhadap ulat krop kubis (Crocidolomia pavartata). Prossiding Seminar Nasional Inovasi Teknologi Pertanian, Banjarbaru.

Badan Litbang Pertanian. 2005. Prospek dan arah pengembangan agribisnis Bawang Merah. Badan Penelitian dan Pengembangan Pertanian, Kementerian Pertanian, Jakarta.

Badan Pusat Statistik. 2017. Produktivitas Sayur di Indonesia 2012-2016. http://bps.go.id (diakses 24 Mei 2018).

Baswarsiati, Sudaryono T, Andri KB, Purnomo S. 2013. Pengembangan varietas Bawang Merah potensial dari Jawa Timur. Balai Pengkajian Teknologi Pertanian (BPTP) Jawa Timur, Jawa Timur.

Bernadip BR, Hadiwiyono H, Sudadi. 2015. Keanekaragaman jamur dan bakteri rizosfer bawang merah terhadap patogen moler. Journal of Soil Science and Agroclimatology. 11(1): 52.

Cho GJ, Lee S-W, Jang KS, Lim HK, Lim $\mathrm{CH}$, et al. 2006. Antifungal activity against Colletotrichum spp. of curcuminoids isolated from Curcuma longa L. Rhizomes. J. Microbiol. Biotechnol. 16(2): 280-285.

Dean R, Van Kan JAL, Pretorius ZA, Hammond-Kosack KE, Di Pietro A, et al. 2012. The Top 10 fungal pathogens in molecular plant pathology: Top 10 fungal pathogens. Molecular Plant Pathology. 13(4): 414-430.
Direktur Jenderal Hortikultura. 2017. Kegiatan dan Program Hortikultura Tahun 2018. Kementerian Pertanian Republik Indonesia. Kementerian Pertanian, Jakarta

Doneche B, Seguin G, Ribereau-Gayon P. 1983. Mancozeb effect on Soil Microorganisms and its degradation in soils. Soil Science. 135(6): 361-366.

Elisabeth DW, Santosa M, Herlina N. 2013. Pengaruh pemberian berbagai komposisi bahan organik pada pertumbuhan dan hasil tanaman bawang merah (Allium ascalonicum L.). Jurnal Produksi Tanaman. 1(3): 21-29.

Hajlaoui H, Trabelsi N, Noumi E, Snoussi M, Fallah H, et al. 2009. Biological activities of the essential oils and methanol extract of tow cultivated mint species (Mentha longifolia and Mentha pulegium) used in the Tunisian folkloric medicine. World Journal of Microbiology and Biotechnology. 25(12): 2227-2238.

Hasanuddin, Rosmayati. 2013. Karakteristik morfologi isolat fusarium penyebab penyakit busuk umbi Bawang Merah. Universitas Sumatera Utara, Pekanbaru.

Javed S, Bashir U. 2012. Antifungal activity of different extracts of Ageratum conyzoides for the management of Fusarium solani. African Journal of Biotechnology. 11(49): 11022-11029. doi: https://doi.org/10.5897/AJB12.366.

Kamboj A, Saluja A. 2008. Ageratum conyzoides L.: A review on its phytochemical and pharmacological profile. International Journal of Green Pharmacy. 2(2): 59-68. doi: http://dx.doi.org/10.4103/09738258.41171.

Lestari I, Umboh SD, Pelealu JJ. 2018. Tingkat populasi jamur tanah akibat perlakuan Fungisida Mankozeb di pertanaman Sayur Kubis (Brassica oleracea var. Capitata) Kecamatan Modoinding, Kabupaten Minahasa Selatan, Sulawesi Utara. Jurnal Bioslogos. 8(1): 26-32. 
Lestiyani A, Wibowo A, Subandiyah S, Identification of Fusarium spp., the causal agent of twisted disease of shallot. Acta Horticulturae. (1128): 155-160.

Malathi S. 2013. Production of cell wall degrading enzymes by Fusarium oxysporum f. sp. cepae causing basal rot of onion and its histopathological changes. International Journal of Plant Protection. 6(2): 412-418.

Michielse CB, Rep M. 2009. Pathogen profile update: Fusarium oxysporum. Molecular Plant Pathology. 10(3): 311324.

Mohamed MSM, Saleh AM, Abdel-Farid IB, El-Naggar SA. 2017. Growth, hydrolases and ultrastructure of Fusarium oxysporum as affected by phenolic rich extracts from several xerophytic plants. Pesticide Biochemistry and Physiology. 141(1): 57-64.

Naguleswaran V, Pakeerathan K, Mikunthan G. 2014. Biological control: A promising tool for Bulb-Rot and Leaf Twisting Fungal Diseases in Red Onion (Allium cepa L.) in Jaffna District. World Applied Sciences Journal. 31(6): 1090-1095.

Okunade AL. 2002. Ageratum conyzoides L. (Asteraceae). Fitoterapia. 73(1): 116.

Patil S, Nargund VB. 2017. Field efficacy of chemicals for the management of twister disease of onion. International Journal of Agricultural Science and Research. 7(1): 343-346.

Patil S, Nargund VB, Hariprasad K, Hegde G, Lingaraju S, et al. 2018. Etiology of Twister Disease Complex in Onion.
Gambley C, Ito S, et al. 2016. International Journal of Current Microbiology and Applied Sciences. 7(12): 3644-3657.

Rahayu E, N Berlian VA. 2000. Bawang Merah. Penebar Swadaya, Jakarta.

Sari EM, Suwirmen, Noli ZA. 2014. Pengaruh penggunaan fungisida (Dithane M-45) terhadap pertumbuhan Tanaman Jagung (Zea mays L.) dan kepadatan spora Fungi Mikoriza Arbuskula (FMA). J. Bio. UA. 3(3): 188-194.

Sugito A, Djatmiko HA, Soesanto L. 2010. Penekanan nabati pada tanah tanaman tomat terkontaminasi Fusarium oxysporum f. sp. lycopersici. Jurnal Ilmu-ilmu Pertanian Indonesia. 12(1): 13-18.

Susanti D, Mulyadi, Wiyatiningsih S. 2016. Karakterisasi isolat-isolat Fusarium oxysporum f. sp. cepae penyebab penyakit moler pada Bawang Merah dari daerah Nganjuk dan Probolinggo. Plumula. 5(2): 153-160.

Vengadaramana A, Costa DMD. 2014. Molecular and pathogenic diversity of the causal agent of Onion Leaf Twister Disease in Batticaloa District of Sri Lanka. Universal Jurnal of Plant Science. 2(7): 121-127.

Wiyatiningsih S. 2010. Pengolahan Epidemi Penyakit Moler pada Bawang Merah. UPN University Press, Surabaya. Xuan TD, Shinkichi T, Hong NH, Khanh TD, Min CI. 2004. Assessment of phytotoxic action of Ageratum conyzoides L. (billy goat weed) on weeds. J. cropro. 23(1): 915-922. 